\title{
Resonance assignment and secondary structure of the middle MA-3 domain and complete tandem MA-3 region of the tumour suppressor protein Pdcd4
}

\author{
Lorna C. Waters $\cdot$ Ojore Oka $\cdot$ Frederick W. Muskett • \\ Sarah L. Strong - Thore Schmedt • \\ Karl-Heinz Klempnauer • Mark D. Carr
}

Received: 7 October 2009/Accepted: 2 December 2009/Published online: 19 December 2009

(C) The Author(s) 2009. This article is published with open access at Springerlink.com

\begin{abstract}
Pdcd4 (Programmed Cell Death Protein 4) is a novel eukaryotic tumour suppressor protein, which is involved in the regulation of both transcription and translation (reviewed in Lankat-Buttgereit and Göke 2009). The protein contains two interacting MA-3 domains (MA- $3_{\mathrm{M}}$ and MA- $3_{C}$ ), which are linked by a short semi-flexible linker region (Waters et al. 2007; Suzuki et al. 2008). The MA-3 domains are involved in mediating specific protein-protein interactions with functional partners such as eIF4A (Yang et al. 2003). Here we report essentially complete backbone and side chain ${ }^{15} \mathrm{~N},{ }^{13} \mathrm{C}$ and ${ }^{1} \mathrm{H}$ assignments for a construct composed of the middle MA-3 domain and subsequent linker region $\left(\mathrm{MA}-3_{\mathrm{M}}\right.$ ) and backbone assignments for the entire tandem MA-3 region of Pdcd4 (Pdcd4 MA-3 ${ }_{\mathrm{M}-\mathrm{C}}$ ). Analysis of the backbone chemical shift data obtained indicates that Pdcd 4 MA- $3_{M}$ contains eight helical regions corresponding to over $74 \%$ of the protein backbone and that Pdcd $4 \mathrm{MA}-3_{\mathrm{M}-\mathrm{C}}$ contains fifteen helical regions (72\%). Comparison of the position of these helical regions with those observed in the crystal structures suggests that the solution and crystal structures of both proteins are very similar.
\end{abstract}

Lorna C. Waters and Ojore Oka are equal first authors.

L. C. Waters $(\bowtie) \cdot$ O. Oka $\cdot$ F. W. Muskett

S. L. Strong - M. D. Carr $(\bowtie)$

Department of Biochemistry, Henry Wellcome Building,

University of Leicester, Lancaster Road,

Leicester LE1 9HN, UK

e-mail:1w83@le.ac.uk

M. D. Carr

e-mail: mdc12@le.ac.uk

T. Schmedt · K.-H. Klempnauer

Institut für Biochemie, Westfälische-Wilhelms-Universität

Münster, Wilhelm-Klemm-Str. 2, 48149 Münster, Germany
Keywords Pdcd4 - MA-3 domain .

NMR resonance assignments · Secondary structure

\section{Biological context}

The eukaryotic regulatory protein Pdcd4 (Programmed Cell Death Protein 4) was initially discovered in a screen for genes activated during apoptosis and later identified as a tumour suppressor in studies of a mouse keratinocyte model of tumour promotion. A number of subsequent studies have also highlighted Pdcd4's role as a tumour suppressor, for example, Pdcd4 has been shown to suppress tumour development in a mouse model of skin carcinogenesis (reviewed in Lankat-Buttgereit and Göke 2009). Pdcd4 has been shown to play critical roles in the regulation of both transcription and translation, mediated via specific protein-protein and perhaps protein-RNA interactions (Bitomsky et al. 2004; Yang et al. 2003).

The 469 residue mouse Pdcd4 protein contains at least three domains, an N-terminal RNA-binding region (residues 1-157) and two interacting MA3 domains (residues 157-275 and 319-449), which are linked by a short semi flexible region (Waters et al. 2007; Suzuki et al. 2008). To date the majority of the molecular and structural studies of Pdcd4 have focused on the interaction between the two MA-3 domains of Pdcd 4 and the eukaryotic translation initiation factor eIF4A, with complex formation resulting in the inhibition of cap-dependent translation (Yang et al. 2003). The structures of both the isolated C-terminal (MA-3 $\mathrm{C}$ ) MA-3 domain, and a construct composed of the middle MA-3 domain and subsequent linker region $\left(\mathrm{MA}-3_{\mathrm{M}}\right)$ of Pdcd4 have been solved and were shown to be composed of three or four layers of atypical HEAT repeats respectively (Waters et al. 2007; Suzuki et al. 2008). More recently, the 
crystal structure of the entire tandem MA-3 region (MA- $3_{\mathrm{M}-\mathrm{C}}$ ) has also been determined (Loh et al. 2009). To date only the assignments for the Pdcd $4 \mathrm{MA}-3_{\mathrm{C}}$ have been deposited (BMRB accession number 6900).

Here we report the determination of essentially complete sequence-specific backbone and side chain assignments for Pdcd4 MA- $3_{M}$ and backbone assignments for Pdcd4 MA- $3_{\text {M-C, }}$ as well as the positions of elements of regular secondary structure.

\section{Methods and experiments}

Unlabelled and uniformly ${ }^{15} \mathrm{~N}$ and ${ }^{15} \mathrm{~N} /{ }^{13} \mathrm{C}$ labelled samples of mouse Pdcd4 MA- $3_{M}$ (residues 157-318) and Pdcd4 MA- $3_{\text {M-C }}$ (residues 157-449) were prepared from pGex-6P2-based E. coli expression vectors essentially as described previously for Pdcd 4 MA-3 ${ }_{C}$ (Waters et al. 2006a), however, for Pdcd $4 \mathrm{MA}-3_{\mathrm{M}-\mathrm{C}}$ transformed cells protein expression was induced for $20 \mathrm{~h}$ at $15^{\circ} \mathrm{C}$. In addition, the cleaved Pdcd 4 constructs and GST were separated by a second round of glutathione based affinity chromatography prior to gel filtration. A ${ }^{13} \mathrm{C}$ labelled Pdcd $4 \mathrm{MA}-3_{\mathrm{M}}$ sample which was used for the ${ }^{13} \mathrm{C} /{ }^{1} \mathrm{H}$ NOESY-HSQC experiment was prepared as described above, but with the addition of nonisotopically labelled aromatic amino acids to the minimal media (His, Phe, Trp and Tyr at $50 \mathrm{mg} / \mathrm{l}$ ).

NMR spectra of Pdcd $4 \mathrm{MA}-3_{\mathrm{M}}$ were acquired from $0.35 \mathrm{ml}$ samples of $0.5-1.5 \mathrm{mM} \mathrm{Pdcd} 4 \mathrm{MA}-3_{\mathrm{M}}$ in a $25 \mathrm{mM}$ sodium phosphate, $100 \mathrm{mM}$ sodium chloride, $0.5 \mathrm{mM}$ DTT, $10 \mu \mathrm{M}$ EDTA, $200 \mu \mathrm{M}$ AEBSF and $0.02 \%(\mathrm{w} / \mathrm{v})$ sodium azide buffer at $\mathrm{pH} 6.5$, containing $10 \% \mathrm{D}_{2} \mathrm{O} / 90 \% \mathrm{H}_{2} \mathrm{O}$ or $100 \% \mathrm{D}_{2} \mathrm{O}$ as appropriate. All NMR data were acquired at $25^{\circ} \mathrm{C}$ on either $600 \mathrm{MHz}$ Bruker Avance/DRX systems or an $800 \mathrm{MHz}$ Bruker Avance II spectrometer. The 2D and 3D spectra recorded to obtain sequence specific assignments for Pdcd4 MA- $3_{M}$ were: ${ }^{1} \mathrm{H}-{ }^{1} \mathrm{H}$ TOCSY with mixing times of 35 and $55 \mathrm{~ms},{ }^{1} \mathrm{H}^{-1} \mathrm{H}$ NOESY with an NOE mixing time of $100 \mathrm{~ms} ;{ }^{15} \mathrm{~N} /{ }^{1} \mathrm{H}$ HSQC; TOCSY-HSQC with a mixing time of $55 \mathrm{~ms}$; NOESY-HSQC with an NOE mixing time of $100 \mathrm{~ms} ;{ }^{13} \mathrm{C} /{ }^{1} \mathrm{H} \mathrm{HCCH}-\mathrm{TOCSY}$ with a mixing time $19.6 \mathrm{~ms},{ }^{13} \mathrm{C} /{ }^{1} \mathrm{H}$ HSQC-NOESY with an NOE mixing time of $100 \mathrm{~ms} ;{ }^{15} \mathrm{~N} /{ }^{13} \mathrm{C} /{ }^{1} \mathrm{H}$ HNCACB, CBCA (CO)NH and HNCO (reviewed in Cavanagh et al. 2006). Typical acquisition times in $F_{1}$ and $F_{2}$ for the $3 D$ experiments were $12-25 \mathrm{~ms}$ for ${ }^{15} \mathrm{~N}, 6.7-9.0 \mathrm{~ms}$ for ${ }^{13} \mathrm{C}(35 \mathrm{~ms}$ for $\mathrm{HNCO}$ experiments) and $15-22.5 \mathrm{~ms}$ for ${ }^{1} \mathrm{H}$, and with an acquisition time of $55-70 \mathrm{~ms}$ in $\mathrm{F}_{3}\left({ }^{1} \mathrm{H}\right)$. Typical acquisition times in $\mathrm{F}_{1}$ for $2 \mathrm{D}$ experiments were $50 \mathrm{~ms}$ for ${ }^{15} \mathrm{~N}$ and $35 \mathrm{~ms}$ for ${ }^{1} \mathrm{H}$, with $80-100 \mathrm{~ms}$ in $\mathrm{F}_{2}$.

NMR spectra of Pdcd $4 \mathrm{MA}-3_{\mathrm{M}-\mathrm{C}}$ were acquired from $0.35 \mathrm{ml}$ samples of $0.15-0.50 \mathrm{mM}$ Pdcd $4 \mathrm{MA}-3_{\mathrm{M}-\mathrm{C}}$ in a $25 \mathrm{mM}$ sodium phosphate, $100 \mathrm{mM}$ sodium chloride,
Fig. 1 Quality of the NMR spectra obtained for Pdcd4 MA- $3_{M}$ and Pdcd4 MA-3 $3_{\text {M-C. }}$. Panel A shows an ${ }^{15} \mathrm{~N} /{ }^{1} \mathrm{H}$ HSQC spectrum of Pdcd4 MA- $3_{\mathrm{M}}$. The assignments of the signals from backbone amide groups are indicated by residue type and number. The region between 6.7 and $7.8 \mathrm{ppm}$ in ${ }^{1} \mathrm{H}$ and 110.0 and $113.3 \mathrm{ppm}$ in ${ }^{15} \mathrm{~N}$ contains, with the exception of E210, S224, T229 and I273, signals from the sidechain amide groups of the asparagine and glutamine residues. The signal located at $10.0 \mathrm{ppm}$ in ${ }^{1} \mathrm{H}$ and $128.4 \mathrm{ppm}$ in ${ }^{15} \mathrm{~N}$ ppm is from the indolic-NH group of $\mathrm{W} 315$. The assignments obtained for overlapped signals in the region between 7.7 and $8.4 \mathrm{ppm}$ in ${ }^{1} \mathrm{H}$ and 116.6 and $122.3 \mathrm{ppm}$ in ${ }^{15} \mathrm{~N}$ are indicated in the enlarged region. Panel $B$ shows an ${ }^{15} \mathrm{~N} /{ }^{1} \mathrm{H}$ HSQC spectrum of Pdcd4 MA- $3_{\mathrm{M}-\mathrm{C}}$ and panel $\mathrm{C}$ a three dimensional view of a ${ }^{15} \mathrm{~N} /{ }^{13} \mathrm{C} /{ }^{1} \mathrm{H}$ HNCO spectrum of Pdcd $4 \mathrm{MA}-3_{\mathrm{M}-\mathrm{C}}$

$2.5 \mathrm{mM}$ DTT, $2.5 \mathrm{mM}$ TCEP, $50 \mu \mathrm{M}$ EDTA, $200 \mu \mathrm{M}$ AEBSF, and $0.02 \%(\mathrm{w} / \mathrm{v})$ sodium azide buffer at $\mathrm{pH} 6.5$, containing $5 \% \mathrm{D}_{2} \mathrm{O} / 95 \% \mathrm{H}_{2} \mathrm{O}$. NMR data were acquired at $35^{\circ} \mathrm{C}$ on an $800 \mathrm{MHz}$ Bruker Avance II spectrometer. The 3D spectra recorded to obtain backbone assignments for Pdcd4 MA- $3_{\mathrm{M}-\mathrm{C}}$ were: ${ }^{15} \mathrm{~N} /{ }^{1} \mathrm{H}$ NOESY-HSQC with an NOE mixing time of $75 \mathrm{~ms}$ and ${ }^{15} \mathrm{~N} /{ }^{13} \mathrm{C} /{ }^{1} \mathrm{H}$ HNCA, HNCO, TROSY-HN(CO)CA and CBCA(CO)NH. Typical acquisition times in $\mathrm{F}_{1}$ and $\mathrm{F}_{2}$ for the $3 \mathrm{D}$ experiments were $10-25 \mathrm{~ms}$ for ${ }^{15} \mathrm{~N}, 6.7-9.0 \mathrm{~ms}$ for ${ }^{13} \mathrm{C}$ (22.5 ms for HNCO experiments) and $16 \mathrm{~ms}$ for ${ }^{1} \mathrm{H}$, and with an acquisition time of $60 \mathrm{~ms}$ in $\mathrm{F}_{3}\left({ }^{1} \mathrm{H}\right)$.

The majority of the 3D spectra were collected over approximately $72 \mathrm{~h}$. The WATERGATE method was used to suppress the water signal when required. The 3D NMR data were processed using Topspin (Bruker Biospin Ltd) with linear prediction used to extend the effective acquisition times by up to twofold in $\mathrm{F}_{1}$ and $\mathrm{F}_{2}$. The spectra were analysed using the Sparky package (T. D. Goddard and D. G. Kneller, SPARKY 3, University of California, San Francisco).

Sequence-specific backbone and side chain resonance assignments were obtained for Pdcd 4 MA- $3_{M}$ using the approach described previously (Waters et al. 2006b). Initially, tentative sequence-specific backbone resonance assignments ( $\mathrm{N}, \mathrm{NH}, \mathrm{C} \alpha$ and $\mathrm{CO}$ ) for Pdcd $4 \mathrm{MA}-3_{\mathrm{M}-\mathrm{C}}$ were obtained by transposing the assignments from the isolated MA-3 domains (acquired at $25^{\circ} \mathrm{C}$ ) onto the triple resonance spectra obtained for Pdcd $4 \mathrm{MA}-3_{\mathrm{M}-\mathrm{C}}$ (acquired at $35^{\circ} \mathrm{C}$ ). Ambiguities between the assignments obtained for the individual MA-3 domains and Pdcd4 MA- $3_{\mathrm{M}-\mathrm{C}}$, arising from differences in the temperature at which the spectra were recorded and/or changes in the chemical environment of residues located at the interface between the two MA-3 domains, were resolved by comparing the amide nitrogen/ proton and carbonyl chemical shifts of residues in $\mathrm{HNCO}$ spectra recorded at a range of temperatures $\left(25\right.$ and $35^{\circ} \mathrm{C}$ for the individual MA-3 domains and 25,30 and $35^{\circ} \mathrm{C}$ for $\mathrm{Pdcd} 4$ MA- $3_{\mathrm{M}-\mathrm{C}}$ ). Finally, the inter-residue amide nitrogen/proton to $\mathrm{C} \alpha$ connectivities observed in triple resonance spectra and the NH to NH NOEs identified in NOESY-HSQC spectra were used to confirm all the assignments made. 

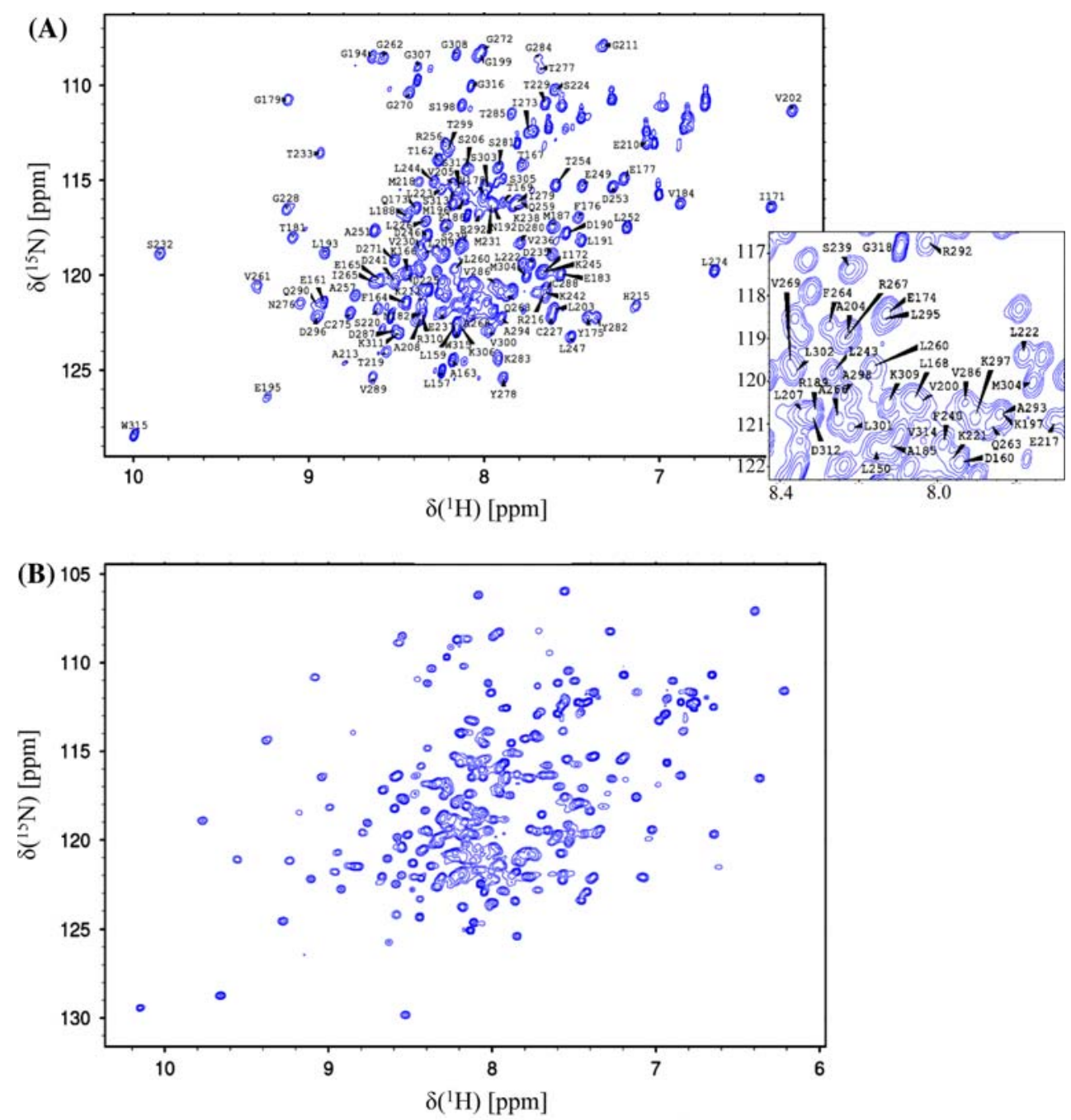

(C)

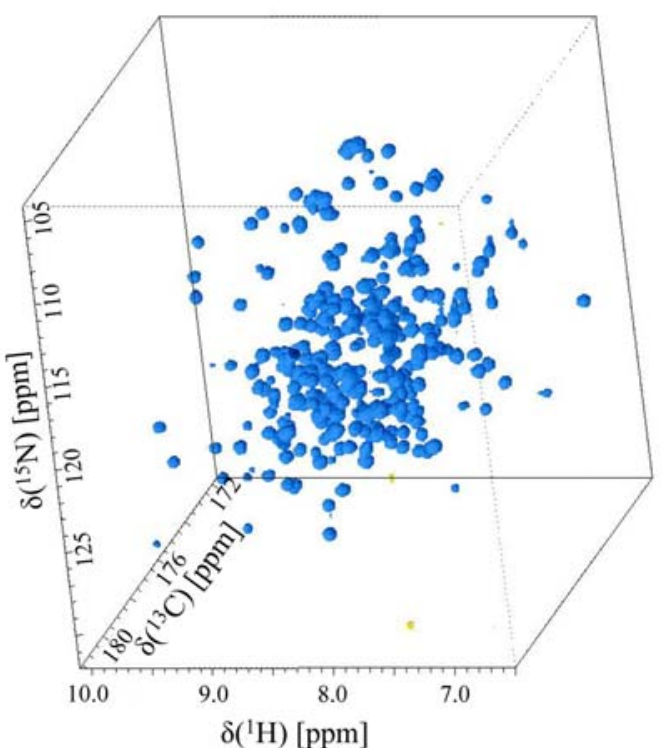



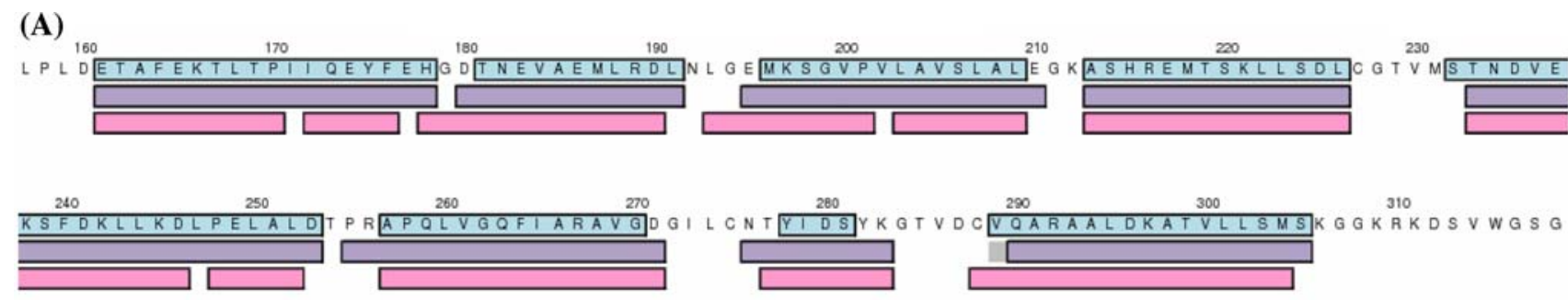

(B)
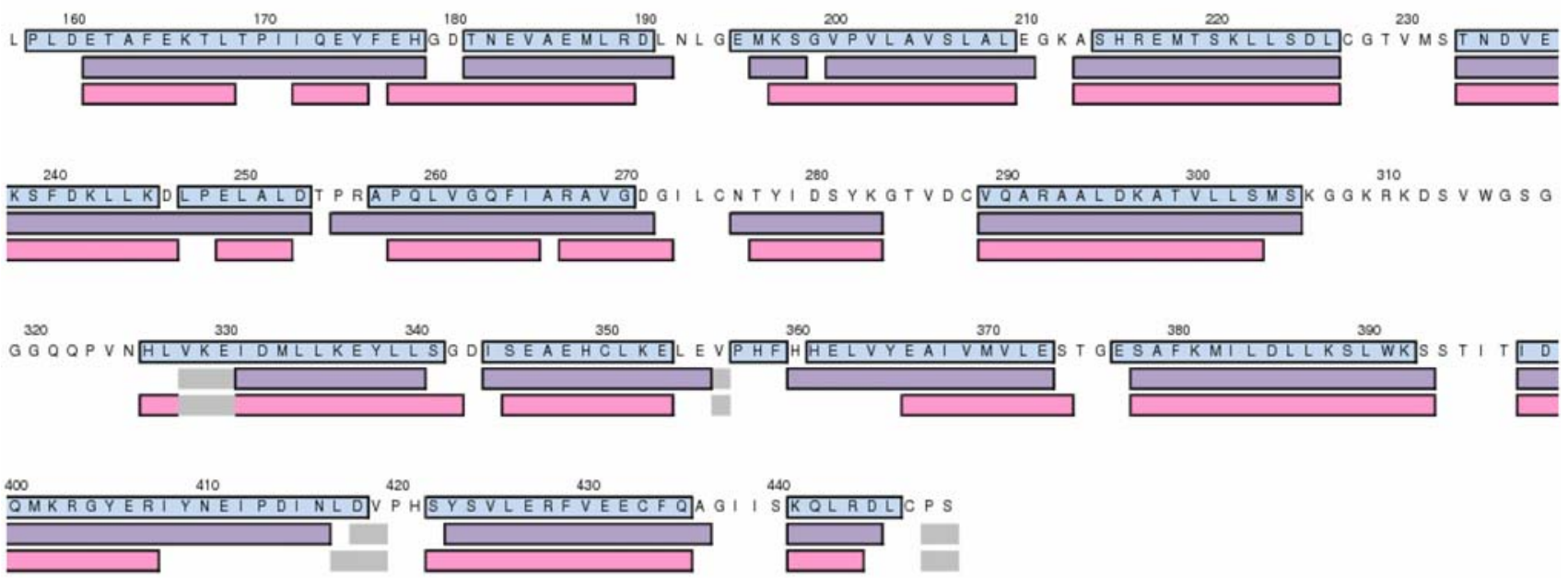

Fig. 2 Location of the secondary structure elements in Pdcd $4 \mathrm{MA}-3_{\mathrm{M}}$ and Pdcd 4 MA- $3_{\mathrm{M}-\mathrm{C}}$. Panel $A$ shows the amino acid sequence of Pdcd 4 MA- $3_{\mathrm{M}}$. Highlighted in blue on the sequence are the positions of the helical regions observed in the crystal structure of Pdcd4 MA$3_{M}$ (Suzuki et al. 2008: PDB code 2RG8). Indicated underneath the sequence in purple and pink are the regions suggested to be helical by the programmes TALOS (shown immediately below) and CSI

\section{Extent of assignments and data deposition}

Pdcd4 MA- $3_{\mathrm{M}}$ gives rise to well-resolved spectra, as illustrated by the ${ }^{15} \mathrm{~N} /{ }^{1} \mathrm{H}$ HSQC spectrum shown in Fig. 1a. This allowed essentially complete backbone resonance assignments to be made. Despite the relatively large size of Pdcd4 MA-3 $3_{\text {M-C }}$ (293 residues) and consequent overlap of signals in $2 \mathrm{D}{ }^{15} \mathrm{~N} /{ }^{1} \mathrm{H}$ HSQC spectra, we were also able to obtain comprehensive sequence-specific backbone resonance assignments. The quality of the NMR spectra obtained is illustrated by the HSQC and HNCO spectra shown in Fig. 1b, c.

Backbone amide assignments were obtained for all residues in Pdcd4 MA- $3_{M}$ except: D180, S214 and A291 (98.1\%), for all $\mathrm{C} \alpha$ and $\mathrm{C} \beta$ signals apart from M218 (C $\beta$ only), C288 and Q290 (98.5\%) and for all CO signals, except for residues followed by a proline, and G179, A213, T233, Q290 and G318 (93.2\%). In the case of $\mathrm{H} \alpha$ and $\mathrm{H} \beta$ signals, assignments were obtained for all residues except: P201, L207 (H $\beta 3$ only), R216, E217 (H $\beta 2, H \beta 3)$, M218 (H $\beta 3$ only), K221 (H $\beta 3$ only), P258, L260, R267, C288, respectively. Residues for which no data could be obtained, due to a lack of input chemical shifts, are highlighted in grey. Panel $B$ shows the amino acid sequence for the entire Pdcd 4 MA- $3_{\mathrm{M}-\mathrm{C}}$ region. Helical regions are indicated as in panel A. In this case, residues highlighted in blue show the positions of the helical regions observed in the crystal structure of Pdcd4 MA- $3_{\text {M-C }}$ (Loh et al. 2009: PDB code 3EIJ)

Q290 and S317 (H $\beta 3$ only) (94.1\%). For the remaining non-exchangeable side chain signals $\left({ }^{13} \mathrm{C}\right.$ and $\left.{ }^{1} \mathrm{H}\right)$ complete assignments were obtained apart from: L188 $\left((\mathrm{H} \delta 2)_{3}\right)$, L193 (C $\gamma), \mathrm{K} 197(\mathrm{H} \varepsilon 3), \mathrm{P} 201(\mathrm{C} \gamma, \mathrm{C} \delta, \mathrm{H} \gamma 2, \mathrm{H} \gamma 3, \mathrm{H} \delta 2$, $\mathrm{H} \delta 3), \mathrm{L} 207(\mathrm{C} \gamma, \mathrm{H} \gamma), \mathrm{R} 216(\mathrm{C} \gamma, \mathrm{C} \delta, \mathrm{H} \gamma 2, \mathrm{H} \gamma 3, \mathrm{H} \delta 2, \mathrm{H} \delta 3)$, P248 (C $\gamma), \mathrm{P} 258(\mathrm{C} \gamma, \mathrm{C} \delta, \mathrm{H} \gamma 2, \mathrm{H} \gamma 3, \mathrm{H} \delta 2, \mathrm{H} \delta 3), \mathrm{L} 260(\mathrm{C} \gamma$, $\left.\mathrm{C} \delta 1, \mathrm{C} \delta 2, \mathrm{H} \gamma,(\mathrm{H} \delta 1)_{3},(\mathrm{H} \delta 2)_{3}\right), \mathrm{R} 267(\mathrm{C} \gamma, \mathrm{C} \delta, \mathrm{H} \gamma 2, \mathrm{H} \gamma 3$, $\mathrm{H} \delta 2, \mathrm{H} \delta 3), \mathrm{V} 269(\mathrm{C} \gamma 1), \mathrm{Q} 290(\mathrm{C} \gamma, \mathrm{H} \gamma 2, \mathrm{H} \gamma 3)$ and $\mathrm{W} 315$ ( $\mathrm{H} \zeta 2, \mathrm{H} \eta 2)(93.5 \%)$.

Backbone amide assignments were obtained for all non-proline residues in Pdcd 4 MA- $3_{\text {M-C }}$ except: D180, S214, A291, G319, H326, V328, K329, E330, I331, V356, H360, T397, D418, V419, S422 and S449 (94.0\%), for all $\mathrm{C} \alpha$ signals except: H326, V328, K329, E330, V356, I415, L417, D418, V419, S422, P448 and S449 (95.9\%), and for all CO signals except residues followed by a proline, and G179, A213, T233, Q290, G318, N325, L327, V328, K329, E330, E355, F359, I396, D414, L417, D418, H421, P448 and S449 (89.8\%). The comprehensive ${ }^{15} \mathrm{~N},{ }^{13} \mathrm{C}$ and ${ }^{1} \mathrm{H}$ resonance assignments obtained for Pdcd4 MA- $3_{\mathrm{M}}$ and Pdcd4 MA- $3_{\mathrm{M}-\mathrm{C}}$ have been deposited 
at the BioMagResBank database (accession numbers 16538 and 16542 respectively).

Analysis of the backbone chemical shifts of Pdcd 4 MA- $3_{M}$, using the programme TALOS (Shen et al. 2009), shows that the domain contains eight helical regions (residues E161-H178, D180-L191, E195-E210, A213-L226, T233-D253, P255-D271, N276-K283 and Q290-S305). These regions are in close agreement with the position of the secondary structure elements observed in the crystal structure of Pdcd $4 \mathrm{MA}-3_{\mathrm{M}}$, as shown in Fig. 2a (Suzuki et al. 2008). Similarly, analysis of the backbone chemical shifts of Pdcd4 MA- $3_{\mathrm{M}-\mathrm{C}}$ showed that there were 15 helical regions (residues E161-H178, T181-L191, M196-E210, A213-L226, T233-D253, P255-D271, N276-K283, V289S305, I331-L340, I344-E355, H360-E373, S378-S393, I398-N416, Y423-A436 and K441-D445). These results are also in close agreement with the position of the secondary structure elements observed in the crystal structure of Pdcd4 MA-3 $3_{\text {M-C }}$, as shown in Fig. 2 b (Loh et al. 2009). The one exception is the absence of the N276-K283 helix in the crystal structure, where this region is instead composed of a series of bends and turns. However, it should be noted that B-factors for this region are somewhat higher than average. The NMR results reported here clearly indicate that the solution and crystal structures of both proteins are very similar.

Acknowledgments This work was supported by grants from the Wellcome Trust (083629, 080085 \& 063632).

Open Access This article is distributed under the terms of the Creative Commons Attribution Noncommercial License which permits any noncommercial use, distribution, and reproduction in any medium, provided the original author(s) and source are credited.

\section{References}

Bitomsky N, Bohm M, Klempnauer K (2004) Transformation suppressor protein Pdcd4 interferes with JNK-mediated phosphorylation of c-Jun and recruitment of the coactivator $\mathrm{p} 300$ by c-Jun. Oncogene 23(45):7484-7493. doi:10.1038/sj.onc.1208064
Cavanagh J, Fairbrother WJ, Palmer AG, Skelton NJ, Rance M (eds) (2006) Chapter 6: experimental ${ }^{1} \mathrm{H}$ NMR methods and chapter 7: heteronuclear NMR experiments. In: Protein NMR Spectroscopy: principles and practice, 2nd edn. Elsevier Academic Press, Amsterdam, pp 406-673

Lankat-Buttgereit B, Göke R (2009) The tumour suppressor Pdcd4: recent advances in the elucidation of function and regulation. Biol Cell 101(6):309-317. doi:10.1042/BC20080191

Loh PG, Yang HS, Walsh MA, Wang Q, Wang X, Cheng Z, Liu D, Song H (2009) Structural basis for translational inhibition by the tumour suppressor Pdcd4. EMBO J 28(3):274-285. doi:10.1038/ emboj.2008.278

Shen Y, Delaglio F, Cornilescu G, Bax A (2009) TALOS+: a hybrid method for predicting protein backbone torsion angles from NMR chemical shifts. J Biomol NMR 44(4):213-223. doi:10.1007/ s10858-009-9333-z

Suzuki C, Garces RG, Edmonds KA, Hiller S, Hyberts SG, Marintchev A, Wagner G (2008) PDCD4 inhibits translation initiation by binding to eIF4A using both its MA3 domains. PNAS 105(9):3274-3279. doi:10.1073/pnas.0712235105

Waters LC, Bohm M, Veverka V, Muskett FW, Frenkiel TA, Kelly GP, Prescott A, Dosanjh NS, Klempnauer KH, Carr MD (2006a) NMR assignment and secondary structure determination of the C-terminal MA-3 domain of the tumour suppressor protein Pdcd4. J Biomol NMR 36(1):18. doi:10.1007/s10858-0055887-6

Waters L, Yue BG, Veverka V, Renshaw P, Bramham J, Matsuda S, Frenkiel T, Kelly G, Muskett F, Carr M, Heery DM (2006b) Structural diversity in p160/CREB-binding protein coactivator complexes. J Biol Chem 281(21):14787-14795. doi:10.1074/jbc. M600237200

Waters LC, Veverka V, Bohm M, Schmedt T, Choong PT, Muskett FW, Klempnauer KH, Carr MD (2007) Structure of the C-terminal MA-3 domain of the tumour suppressor protein Pdcd4 and characterization of its interaction with eIF4A. Oncogene 26(34): 4941-4950. doi:10.1038/sj.onc. 1210305

Yang HS, Jansen AP, Komar AA, Zheng X, Merrick WC, Costes S, Lockett SJ, Sonenberg N, Colburn NH (2003) The transformation suppressor Pdcd4 is a novel eukaryotic translation initiation factor 4A binding protein that inhibits translation. Mol Cell Biol 23(1):26-37. doi:10.1128/MCB.23.1.26-37.2003 